\title{
Erratum
}

\section{Aldosterone synthase C-344T, angiotensin II type 1 receptor A1166C and 11- $\beta$ hydroxysteroid dehydrogenase G534A gene polymorphisms and essential hypertension in the population of Odisha, India}

\author{
Manisha Patnaik, Pallabi Pati, Surendra N. Swain, Manoj K. Mohapatra, Bhagirathi Dwibedi, Shantanu K. Kar \\ and Manoranjan Ranjit \\ J. Genet. 93, 799-808
}

Table 6 footer should read: '*Females were neither smokers nor alcoholics; $P$, significance; exp(B), exponentiation of the beta coefficient, an odds ratio. Other abbreviations used are same as in table 1.' 